\title{
Geoquímica
}

\section{EARLY ARC MAGMATISM: \\ GEOCHEMICAL CHARACTERISTICS OF VOLCANIC CLASTS FROM PUNTA SÁMARA, COSTA RICA}

\author{
Lina C. Patino ${ }^{1 *}$, Guillermo E. Alvarado ${ }^{2} \&$ Thomas A. Vogel ${ }^{1}$ \\ ${ }^{1}$ Department of Geological Sciences, Michigan State University, \\ East Lansing MI 48824, USA \\ ${ }^{2}$ Escuela Centroamericana de Geología, Universidad de Costa Rica, \\ Apdo. 214-2060, Costa Rica \\ * Corresponding author: patinol@msu.edu
}

(Recibido 02/03/03; aceptado 02/07/03)

\begin{abstract}
The geochemical characteristics of volcaniclasts from Punta Sámara are used to infer magmatic processes that generated Late Cretaceous - Middle Paleocene arc lavas in the western margin of the Caribbean plate. The $\mathrm{Ba} / \mathrm{La}$ ratios of the volcaniclasts are higher than the ratios for any of the modern lavas from Costa Rica, and the $\mathrm{La} / \mathrm{Yb}$ ratios are lower; suggesting that the lavas from the primitive arc were generated by greater contribution of slab material than the modern arc lavas. Furthermore, the lower $\mathrm{La} / \mathrm{Yb}$ ratios imply that the degree of melting was significantly higher and/or that the mantle source was more depleted than in modern Costa Rica. The low $\mathrm{Zr} / \mathrm{Nb}$ ratios for the modern lavas from central Costa Rica imply a more enriched mantle source (OIB-like), whereas the higher ratios for the primitive arc volcaniclasts imply a more depleted mantle source (MORB-like). We use the geochemical information to infer the conditions of subduction during the early stages of arc magmatism in the southern part of the Central American arc. We infer that the primitive arc was associated with a subducting slab that dip at a steeper angle than the present. The steeper angle would imply that the subducting Farallon plate was older, colder and denser than the present Cocos plate.
\end{abstract}

Keywords: Punta Sámara, volcaniclasts, arc magmatism, geochemistry, primitive arc, slab.

RESUMEN: Se usan las características geoquímicas de los volcaniclastos de Punta Sámara, para inferir los procesos magmáticos que generaron las lavas de arco en el Cretácico tardío - Paleoceno Medio. Las relaciones Ba/La son más altas que las de las lavas jóvenes de Costa Rica y las de La/Yb son más bajas, lo que sugiere que las lavas del arco primitivo se generaron por una mayor contribución del material de la placa subducida que las lavas del arco moderno. Además, las relaciones más bajas de La/Yb implican que el grado de fusión era significativamente más alto y/o la fuente mantélica estaba más empobrecida que en la actualidad. La baja razón de $\mathrm{Zr} / \mathrm{Nb}$ para las lavas jóvenes de Costa Rica central implica una fuente mantélica más enriquecida (tipo OIB), mientras que las razones mayores para los volcaniclastos del arco primitivo implican una fuente mantélica más empobrecida (tipo MORB). Usamos la información geoquímica para inferir las condiciones de la subducción durante las etapas tempranas del magmatismo en la parte sur del arco de América Central. Inferimos que el arco primitivo estaba asociado con una placa que se subducía a un ángulo mayor que el presente, lo que implicaría que la subducida placa Farallón era más vieja, fría y densa que la actual placa del Coco.

Palabras clave: Punta Sámara, volcaniclastos, magmatismo de arco, geoquímica, arco primitivo, placa subducida. 


\section{INTRODUCTION}

The Central American volcanic arc on the western margin of the Caribbean plate is the product of the subduction of the Cocos plate underneath the Caribbean plate. The interaction between these two tectonic plates has occurred since Late Oligocene - Early Miocene (Hey, 1977). However, there is considerable geologic evidence that indicates that arc related volcanism on the western margin of the Caribbean plate is significantly older than 23 Ma (e.g., Bourgois et al., 1984; Meschede et al., 1988; Maury et al., 1995; Hauff et al., 2000; Lissinna et al., 2002). The ancient volcanic chain was the result of the convergence of the Caribbean and the Farallon plates (e.g., Pindell \& Barrett, 1990; Hauff et al., 2000; Hoernle et al., 2002).

Tectonic reconstructions indicate that the earliest manifestations of arc related volcanism in southern Central America are found in formations from the Aptian (124 Ma) to the Eocene (Bourgois et al., 1984; Tournon, 1984; Calvo \& Bolz, 1994; Hauff et al., 2000; Hoernle et al., 2002; Lissinna et al., 2002) located along the Pacific coast. Hauff et al. (2000) indicate the presence of arc related rocks (124-109 Ma) in the Santa Elena peninsula in Costa Rica. These rocks are found in geologic formations that have been displaced from their original location, although it has not yet been determined. Calvo \& Bolz (1994) indicate the presence of arc related sediments in Loma Chumico Formation (100 - 75 Ma). However, this characterization has to be confirmed with detailed chemical analyses. Cobbles of andesitic composition, with fresh zoned plagioclase and amphibole crystals are abundant in Campanian - Paleocene turbidite deposits on the Pacific coast in Costa Rica (Kuijpers, 1979; Lew, 1983). Expressions of the older arc are also found in Nicaragua and Panama. Weyl (1980) indicates that volcaniclastic sediments (Cenomanian to Eocene) on the Nicaraguan Trough are manifestations of Cretaceous - Tertiary subduction related magmatism on the southeastern edge of Central America. Lissinna et al. (2002) report calc-alkaline lavas in western Panama that range in age from 48.8 to 60.89 Ma. In addition, Maury et al. (1995) relate Late Eocene sandstones and shales in eastern Panama to an early magmatic arc.

Volcaniclastic materials are used to reconstruct tectonic and petrologic histories in a wide range of tectonic settings (Fisher \& Schmincke 1984; Cas \& Wright, 1987). For example, Schott \& Johnson (1998) document the sedimentary record of the Late Cretaceous Salina-Mojave magmatic arc (Gualala basin, California). Geochemical data lead them to infer the arc-related origin of conglomerate igneous clasts associated with the Cretaceous Cordilleran arc in the USA. In their study of the origin of Sumba region, Indonesia, Lytwyn et al. (2001) conclude that the geochemistry of Cretaceous turbidite deposits indicates a close proximity to an intra-oceanic island arc. The volcaniclasts that are used to infer tectonic and magmatic histories of active or ancient arc systems are volcanic material that has been mobilized over some distance through processes like debris avalanches and/or lahars. A modern analog has been described by Ballance (1991), who indicates that the upper trench slope of the Tonga arc is dominated by coarse-grained turbidites and debris flows. However, volcaniclastic deposits are not only found in fore-arc regions. Hathway \& Kelly (2000) document clast-supported conglomerates as part of a late Cretaceous volcanic succession in the backarc Larsen Basin in Sobral Peninsula, Antarctica.

This paper summarizes the geochemical characteristics of volcaniclasts from Punta Sámara (Fig. 1) that represent Late Cretaceous Middle Paleocene arc lavas and correspond to a localized view on the evolution of the Central American arc. The compositions of the primitive arc lavas are compared to the compositions of modern lavas from Costa Rica to gain insight on subduction parameters for the primitive arc (e.g., mantle and slab composition, and dip angle for the subducting plate).

\section{ANALYTICAL PROCEDURE}

Cobbles of volcanic origin were collected from a turbidite deposit in the northern part of Punta Sámara. The samples were cut so only the 


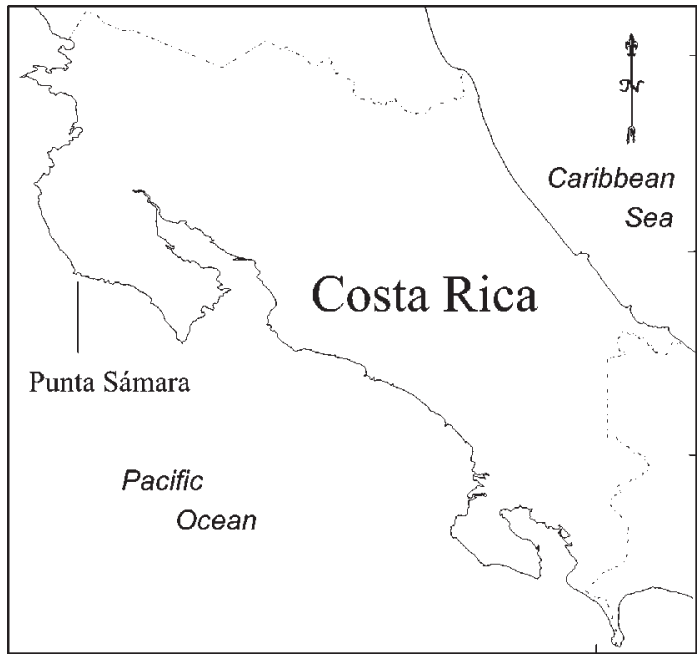

Fig. 1: Location map. Punta Sámara, in the Nicoya Peninsula, is marked.

innermost part was used to prepare them for thin section and chemical analyses. Two types of whole rock chemical analyses were done: X-ray fluorescence (XRF) and laser ablation Inductively Coupled Plasma Mass Spectrometry (LA-ICP-MS). Major-element and selected trace-element concentrations were determined by XRF in a Rigaku SMAX. Additional trace element concentrations were determined by LAICP-MS using a Cetac LSX-200 ${ }^{+}$and a Micromass Platform ICP-MS.

Glass disks were made by mixing the finely ground rock powder with lithium tetraborate as a flux, and ammonium nitrate as an oxidizer. The proportions were $3 \mathrm{~g}$ rock, $9 \mathrm{~g}$ lithium tetraborate and $0.5 \mathrm{~g}$ ammonium nitrate. These materials were mixed, fused at $1000^{\circ} \mathrm{C}$ in a platinum crucible in an oxidizing flame for at least 30 minutes, and then poured into platinum molds. The glass disks were analyzed by XRF and LA-ICP-MS. XRF data for major-elements were processed using fundamental parameter reduction method (Criss, 1980) with XRFWIN software (Omni Instruments), with a precision of $<1 \%$ for most elements and $<3 \%$ for $\mathrm{TiO}_{2}$ and $\mathrm{P}_{2} \mathrm{O}_{5}$. Total $\mathrm{Fe}$ is reported as $\mathrm{Fe}_{2} \mathrm{O}_{3}$. XRF traceelement analyses were reduced by standard linear regression techniques. For LA-ICP-MS results, strontium (determined by XRF on the same disks) was used as the internal standard. Prior to any calculation the background signal was subtracted from standards and samples. The concentrations were calculated based on linear regression techniques using USGS and Japanese standards; only standards that were within $15 \%$ of their known concentration were used to determine the calibration lines. Thus, the concentrations of the samples are inferred to have errors $<15 \%$. The standards span a wide range of silicate rock compositions, ensuring that unknown samples are within the range of the standards.

\section{RESULTS}

The clasts from the primitive arc are cobbles in turbidites deposited between the Upper Maastrichtian and Lower-Middle Paleocene (Baumgartner et al., 1984). The authors note that the clasts are included in submarine high density flows from an unstable shallow platform, including coastal cliffs. The clasts likely originated from mechanical weathering of lava flows, and the degree of chemical alteration varies. A common way to discriminate rocks that have been altered by secondary processes is using chemical indices of alteration (e.g. Morey \& Setterholm, 1997; Hill et al., 2000). To determine if the volcanic cobbles were useable for a petrogenetic study, we use the Weathering Index (WI) suggested by Parker (1970) to infer the relative degree of chemical weathering in the volcaniclasts. This index was chosen because it is more sensitive to the chemical variations in the early stages of alterations. In the case of the volcaniclasts from Punta Sámara, most of the samples have a weathering index that is within the range of that of modern arc lavas (Fig. 2). This information along with other geochemical data (e.g., REE patterns) implies that the degree of chemical weathering was minimum.

In some samples, phenocrysts were pristine; whereas in other samples the phenocrysts were completely replaced by secondary minerals such as calcite and chlorite. Only the least altered clasts were selected for the petrogenesis study. In these samples the alteration was restricted to the 


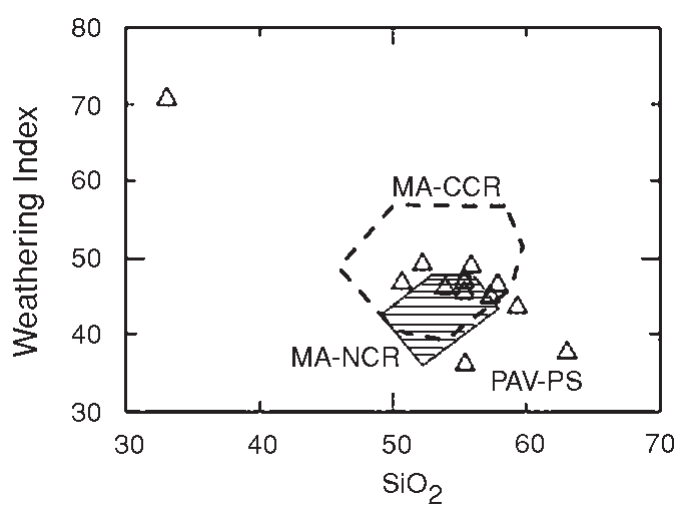

Fig. 2: $\mathrm{SiO}_{2}$ vs. Weathering Index (Parker, 1970). This diagram was used to discriminate among samples that were chemically altered. PAV-PS: Primitive Arc Volcaniclasts - Punta Sámara. MA-CCR: lavas from Modern Arc in Central Costa Rica. MA-NCR: lavas from the Modern Arc in Northern Costa Rica.

groundmass, which takes a reddish tint. Mineralogically the volcaniclasts consist of plagioclase, pyroxenes, and opaque phenocrysts. These phenocrysts range from subhedral to euhedral. The groundmass is hypocrystalline with a mineral assemblage similar to that of the phenocrysts.

The compositions of the volcaniclasts range from evolved tholeiitic basalts to andesites $\left(\mathrm{SiO}_{2}\right.$ varies from 50 to 63 wt.\%; major element data has been normalized; Table 1) with low $\mathrm{MgO}(<4$ wt. $\%), \mathrm{Ni}(<20 \mathrm{ppm})$, and $\mathrm{Cr}(<20$ ppm). $\mathrm{MgO}$ values are lower compared to samples from the modern arc in Costa Rica (Fig. 3). However, there is little change in the abundance of trace elements relative to $\mathrm{SiO}_{2}$ in the older samples compared to the modern volcanic material. The volcaniclastic samples display enrichment of large ion lithophile elements (LILE) relative to light rare earth elements (LREE) and high field strength elements (HFSE; Fig. 4), characteristic of magmas associated with subduction zone magmatism. The depletion of HFSE, particularly niobium is greater for the primitive arc volcaniclasts than for the modern arc lavas. The samples from the primitive arc are less enriched in LREE than the lavas from the modern arc, with the lavas from central Costa Rica being the most enriched in LREE.

DISCUSSION AND CONCLUSION

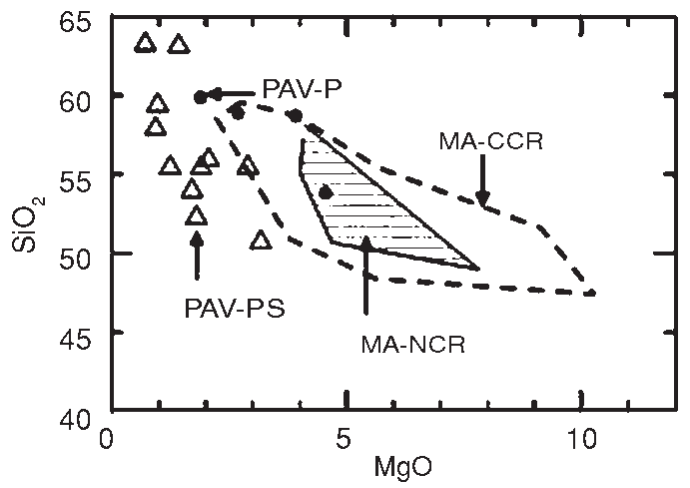

Fig. 3: $\mathrm{MgO}$ vs. $\mathrm{SiO}_{2}$. The more evolved nature of the volcaniclasts from Punta Sámara (PAV-PS) is inferred based on their lower $\mathrm{MgO}$ concentrations relative to similar $\mathrm{SiO}_{2}$ when compared to modern arc in central and northern Costa Rica (MA-CCR and MA-NCR) and primitive arc volcaniclasts from Panama (PAV-P).

The trace element composition of the volcaniclasts clearly suggests that these samples were likely generated in an arc setting (Fig. 4). Comparing the trace element composition of the volcaniclasts from Punta Sámara (this study) and from Panama (Maury et al., 1995) with that of modern lavas from Costa Rica we can infer some physical and chemical characteristics of the arc in the earliest stages of magmatism in the southern part of Central America. Samples from both the primitive and the modern arcs display $\mathrm{Ba} / \mathrm{La}$ gre-

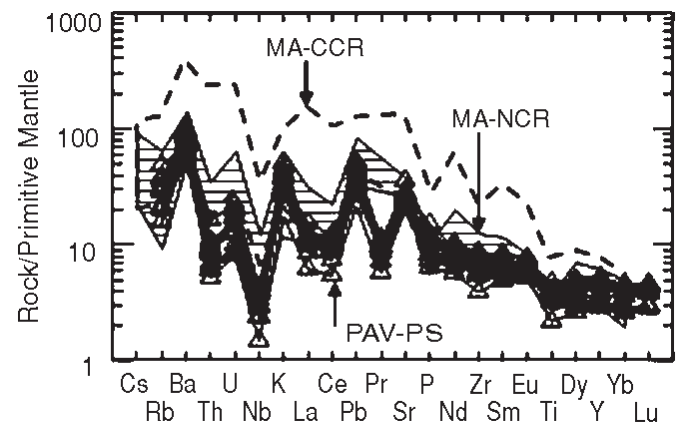

Fig. 4: Primitive mantle normalized diagram. The PAV samples display depletion of $\mathrm{Nb}$ relative to rare earth elements (REE) and large ion lithophile elements (LILE) characteristic of arc related volcanic products. Normalization factors from Sun \& McDough (1989). 
Table 1

Chemical analyses of Punta Sámara volcaniclasts

\begin{tabular}{|c|c|c|c|c|c|c|c|c|c|c|c|c|}
\hline & PA5 & PA6 & PA8 & PA9 & PA10 & PA11 & PA12 & PA13 & PA14 & PA15 & PA18 & PA19 \\
\hline \multicolumn{13}{|c|}{ XRF } \\
\hline $\mathrm{SiO}_{2}$ & 63.20 & 55.36 & 50.67 & 52.22 & 63.07 & 57.85 & 59.34 & 55.37 & 53.92 & 55.41 & 55.87 & 33.06 \\
\hline $\mathrm{TiO}_{2}$ & 0.70 & 0.91 & 1.08 & 0.86 & 0.48 & 0.85 & 0.86 & 0.75 & 0.76 & 0.72 & 0.89 & 0.46 \\
\hline $\mathrm{Al}_{2} \mathrm{O}_{3}$ & 18.19 & 18.94 & 18.26 & 19.62 & 16.66 & 19.75 & 19.2 & 18.63 & 18.92 & 19.36 & 19.3 & 12.24 \\
\hline $\mathrm{Fe}_{2} \mathrm{O}_{3}$ & 4.99 & 8.17 & 9.42 & 8.11 & 6.72 & 5.34 & 6.23 & 6.68 & 6.55 & 8.65 & 7.07 & 4.62 \\
\hline $\mathrm{MnO}$ & 0.05 & 0.10 & 0.25 & 0.15 & 0.12 & 0.10 & 0.07 & 0.24 & 0.28 & 0.17 & 0.10 & 0.33 \\
\hline $\mathrm{MgO}$ & 0.71 & 1.90 & 3.17 & 1.80 & 1.42 & 0.93 & 0.97 & 1.24 & 1.70 & 2.89 & 2.06 & 1.54 \\
\hline $\mathrm{CaO}$ & 7.31 & 9.53 & 12.39 & 12.07 & 7.02 & 9.68 & 8.19 & 11.94 & 13.24 & 9.43 & 8.80 & 44.72 \\
\hline $\mathrm{Na}_{2} \mathrm{O}$ & 3.70 & 3.76 & 3.61 & 3.33 & 3.41 & 4.01 & 3.80 & 3.78 & 3.54 & 2.70 & 4.26 & 2.34 \\
\hline $\mathrm{K}_{2} \mathrm{O}$ & 0.91 & 1.15 & 0.88 & 1.60 & 0.93 & 1.23 & 1.15 & 1.03 & 0.86 & 0.53 & 1.37 & 0.57 \\
\hline $\mathrm{P}_{2} \mathrm{O}_{5}$ & 0.23 & 0.18 & 0.26 & 0.25 & 0.16 & 0.26 & 0.18 & 0.34 & 0.23 & 0.14 & 0.27 & 0.12 \\
\hline Total & 100 & 100 & 100 & 100 & 100 & 100 & 100 & 100 & 100 & 100 & 100 & 100 \\
\hline $\mathrm{Rb}$ & 12.8 & 22.9 & 19.3 & 31.0 & 13.6 & 23.2 & 19.8 & 18.0 & 13.2 & 10.0 & 24.2 & 7.5 \\
\hline $\mathrm{Sr}$ & 554.6 & 535.1 & 472 & 550.1 & 503.2 & 511.9 & 503.6 & 591.3 & 488.8 & 425.7 & 757.2 & 522.6 \\
\hline $\mathrm{Y}$ & 14.37 & 20.15 & 23.41 & 19.74 & 12.97 & 23.46 & 22.65 & 22.63 & 20.11 & 16.84 & 14.23 & 5.52 \\
\hline $\mathrm{Zr}$ & 92.0 & 60.7 & 79.4 & 64.1 & 66.5 & 94.1 & 94.0 & 87.3 & 73.7 & 43.7 & 95.8 & 34.4 \\
\hline \multicolumn{13}{|c|}{ LA ICP-MS } \\
\hline $\mathrm{Nb}$ & 2.92 & 1.67 & 2.42 & 2.03 & 1.72 & 2.72 & 2.78 & 2.80 & 2.17 & 1.06 & 2.98 & 1.01 \\
\hline $\mathrm{Ba}$ & 676.04 & 420.63 & 383.26 & 501.55 & 594.68 & 566.04 & 535.88 & 613.50 & 472.9 & 434.25 & 600.55 & 297.8 \\
\hline $\mathrm{La}$ & 7.29 & 7.39 & 6.74 & 8.14 & 5.85 & 8.54 & 7.15 & 10.62 & 7.78 & 4.24 & 8.03 & 3.00 \\
\hline $\mathrm{Ce}$ & 18.39 & 15.58 & 16.11 & 17.25 & 13.27 & 20.41 & 17.88 & 21.49 & 17.35 & 9.72 & 17.58 & 6.58 \\
\hline $\operatorname{Pr}$ & 2.50 & 2.37 & 2.61 & 2.62 & 1.99 & 3.13 & 2.93 & 3.06 & 2.67 & 1.59 & 2.61 & 0.92 \\
\hline $\mathrm{Nd}$ & 10.34 & 10.69 & 12.26 & 11.71 & 8.79 & 13.83 & 13.78 & 12.79 & 11.44 & 7.61 & 11.13 & 3.71 \\
\hline $\mathrm{Sm}$ & 2.58 & 2.88 & 3.23 & 2.97 & 2.22 & 3.55 & 3.73 & 3.08 & 2.94 & 2.20 & 2.73 & 0.96 \\
\hline $\mathrm{Eu}$ & 1.00 & 1.01 & 1.19 & 1.10 & 0.86 & 1.29 & 1.26 & 1.13 & 1.12 & 0.89 & 1.23 & 0.41 \\
\hline $\mathrm{Gd}$ & 2.69 & 3.22 & 3.60 & 3.12 & 2.30 & 3.73 & 3.80 & 3.24 & 3.13 & 2.48 & 2.77 & 1.27 \\
\hline $\mathrm{Tb}$ & 0.46 & 0.55 & 0.62 & 0.54 & 0.42 & 0.63 & 0.67 & 0.57 & 0.53 & 0.49 & 0.48 & 0.22 \\
\hline Dy & 2.12 & 3.02 & 3.60 & 3.10 & 1.91 & 3.45 & 3.71 & 3.05 & 3.02 & 2.51 & 2.30 & 0.72 \\
\hline Ho & 0.45 & 0.62 & 0.74 & 0.61 & 0.37 & 0.68 & 0.73 & 0.62 & 0.60 & 0.53 & 0.45 & 0.13 \\
\hline Er & 1.45 & 2.09 & 2.37 & 2.04 & 1.15 & 2.38 & 2.36 & 2.05 & 1.83 & 1.65 & 1.45 & 0.38 \\
\hline $\mathrm{Yb}$ & 1.40 & 2.16 & 2.24 & 1.92 & 1.27 & 2.20 & 2.20 & 2.06 & 1.91 & 1.76 & 1.43 & 0.76 \\
\hline $\mathrm{Lu}$ & 0.22 & 0.34 & 0.33 & 0.31 & 0.21 & 0.33 & 0.33 & 0.32 & 0.28 & 0.29 & 0.22 & 0.10 \\
\hline $\mathrm{Ta}$ & 0.16 & 0.13 & 0.14 & 0.12 & 0.09 & 0.16 & 0.16 & 0.16 & 0.13 & 0.06 & 0.18 & 0.08 \\
\hline $\mathrm{Hf}$ & 1.96 & 1.61 & 2.08 & 1.65 & 1.62 & 2.24 & 2.52 & 2.14 & 1.82 & 1.13 & 2.32 & 0.43 \\
\hline $\mathrm{Pb}$ & 3.62 & 2.07 & 1.88 & 2.12 & 2.95 & 3.31 & 2.53 & 2.54 & 2.32 & 1.51 & 3.57 & 1.81 \\
\hline Th & 0.74 & 0.52 & 0.52 & 0.82 & 0.59 & 0.71 & 0.76 & 0.92 & 0.78 & 0.44 & 1.38 & 0.18 \\
\hline $\mathrm{U}$ & 0.37 & 0.18 & 0.21 & 0.26 & 0.18 & 0.41 & 0.36 & 0.31 & 0.36 & 0.17 & 0.47 & 0.86 \\
\hline
\end{tabular}

Major elements in wt\% and trace elements in ppm.

ater than those observed in MORB and OIB (<15; Fig. 5). Based on $\mathrm{Ba} / \mathrm{La}$ and $\mathrm{La} / \mathrm{Yb}$ ratios, Carr et al. (1990) show that the amount of slab contribution and degree of melting varied along the modern Central American arc. They interpret the low $\mathrm{Ba} / \mathrm{La}$ and high $\mathrm{La} / \mathrm{Yb}$ ratios of the modern lavas from Costa Rica as an indication that the magmas were generated by low degrees of mantle melting with a small slab contribu- tion. The extreme case is observed in the modern lavas from central Costa Rica, which have the highest $\mathrm{La} / \mathrm{Yb}$ and lowest $\mathrm{Ba} / \mathrm{La}$ ratios (Fig. 5). The $\mathrm{Ba} / \mathrm{La}$ ratios of the volcaniclasts from Punta Sámara (50-120) are higher than the ratio for any of the modern lavas from Costa Rica and higher than the volcaniclasts from Panama. These high ratios are within the range observed in other segments of the modern arc 


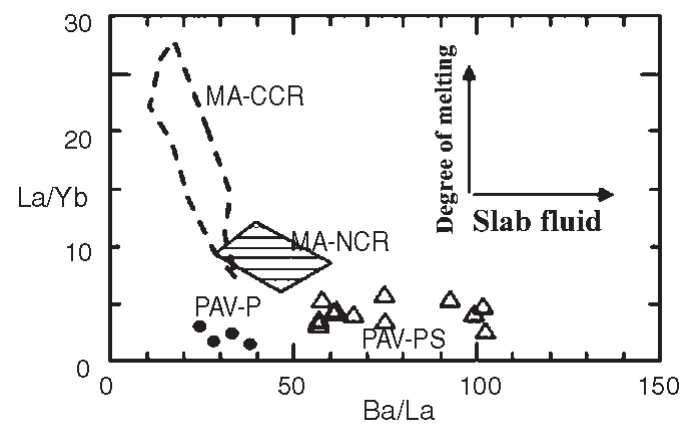

Fig. 5: $\mathrm{Ba} / \mathrm{La}$ vs. $\mathrm{La} / \mathrm{Yb}$. The volcaniclasts from the primitive arc (PAV-PS) display higher $\mathrm{Ba} / \mathrm{La}$ and lower $\mathrm{La} / \mathrm{Yb}$ ratios than samples from the modern arc in central and northern Costa Rica (MA-CCR and MA-NCR), implying that the PAV-PS originated from high degrees of melting of metasomatized mantle.

that have been interpreted to represent the highest slab contribution along the modern Central American arc (Carr et al., 1990). Following this reasoning, we can infer that the lavas from the primitive arc represented by the volcaniclasts from Punta Sámara were generated by greater contribution of slab material than the modern Costa Rican arc lavas or than primitive arc volcaniclasts from Panama. Moreover, the lower $\mathrm{La} / \mathrm{Yb}$ ratios for the volcaniclasts imply that the degree of melting was significantly higher and/or that the mantle source was more depleted than in modern Costa Rica.

The model that Carr et al. (1990) present for the modern arc indicates that the along-arc variations in slab contribution and degree of melting are related to the variations in the subducting angle of the Cocos Plate underneath the Caribbean Plate. The angle is steeper in Nicaragua and shallower in central Costa Rica. The authors indicate that the shallow angle favors the metasomatism over a greater volume of mantle, which will melt to lower extents. On the other hand, steeper angle will favor the metasomatism over a smaller volume in the mantle, which will induce greater degree of melting. Applying this reasoning to the primitive arc, we infer that there was a steeper angle of subduction during the Mesozoic than the present. The steeper angle would imply that the subducting Farallon Plate was older, colder and denser than the present Cocos Plate. There is a wide range in the $\mathrm{Ba} / \mathrm{La}$ ratios of the volcaniclasts from Costa Rica and those from Panama. With the present data set, it would be impossible to discern if this range is due to variations on the geometry of the subducting slab along the arc (as it is inferred for the modern arc) or if they are produced by differences in the nature of subducted material. To answer this question, it is indispensable for the volcaniclasts to be accurately dated. Accurate dates will allow us to infer if the two primitive arcs are related in space and time.

The trace element ratios that Carr et al. (1990) used are good indicators to infer the overall slab contribution and the degree of melting. Feigenson \& Carr (1993), using REE variations along the Central American arc, indicate that the mantle source for the lavas from Costa Rica had a higher garnet-clinopyroxene ratio than other regions of the arc. Their observations of a different mantle composition along the central Costa Rican portion of the arc were confirmed later using $\mathrm{Pb}$ isotopes (Herrstrom et al., 1995; Feigenson et al., 1996; Abratis \& Worner 2000). In other arcs, like the Marianas, Woodhead et al. (1998) proposed that the $\mathrm{Zr} / \mathrm{Nb}$ ratios are controlled by the mantle source. Melts produced from a more depleted mantle tend to have lower $\mathrm{Nb}$ concentrations. Abratis \& Worner (2000) also used $\mathrm{Nb}-\mathrm{Zr}$ ratios to correlate changes in the mantle composition for lavas from southern Costa Rica. The Costa Rican volcanic products, modern and primitive, present a wide range of distribution of $\mathrm{Zr} / \mathrm{Nb}$ ratios (Fig. 6). The primitive arc samples and the modern lavas from central Costa Rica have a restricted $\mathrm{Zr} / \mathrm{Nb}$ ratio ( $\sim 35$ and $\sim 12$, respectively), whereas this ratio varies significantly in modern lavas from northern Costa Rica ( 5 to 70$)$ and in volcaniclasts from Panama. A more constant $\mathrm{Zr} / \mathrm{Nb}$ ratio can be interpreted as a more homogenous mantle component. The lower $\mathrm{Zr} / \mathrm{Nb}$ ratios for the modern lavas from central Costa Rica imply a more enriched mantle source, whereas the higher ratios for the primitive arc volcaniclasts imply a more depleted mantle source. The lavas from northern Costa Rica, with their varied $\mathrm{Zr} / \mathrm{Nb}$ ratios, can be interpreted as being generated from a heterogeneous mantle source; some lavas are 


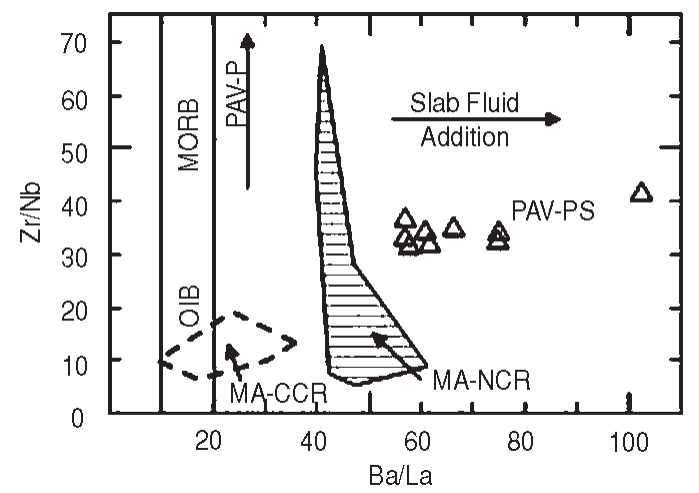

Fig. 6: $\mathrm{Ba} / \mathrm{La}$ vs. $\mathrm{Zr} / \mathrm{Nb}$. The $\mathrm{Zr} / \mathrm{Nb}$ ratio for PAV-PS samples is tighter than the range observed in northern Costa Rica lavas (MA-NCR) and the values are higher than in central Costa Rica (MA-CCR) samples.

generated from an enriched source (lower $\mathrm{Zr} / \mathrm{Nb}$ ) and other lavas are generated from a more depleted source (higher $\mathrm{Zr} / \mathrm{Nb}$ ). The heterogeneity in the mantle composition can be due to a longer period of metasomatism, or it may be due to "patchy" mantle. Other authors have indicated that the lavas from northern Costa Rica can be interpreted to have contributions from an N-MORB and from a more enriched mantle source (OIB-like). The NMORB mantle domain prevails in northern Central America and the more enriched domain prevails in central Costa Rica (Herrstrom et al., 1995, Abratis \& Worner, 2000). The source of the enriched mantle in central Costa Rica has been related to the subduction of the aseismic Cocos Ridge (Abratis \& Worner, 2000, Herrstrom et al., 1995, Feigenson et al., 1996).

Comparing the trace element ratios for the modern and primitive arc, we can also make first order inferences on the composition of the subducting sediments (Fig. 7) during the two time periods: a) the subduction of the Farallon plate and, b) the subduction of the Cocos plate. The sediments related to the modern arc are divided into two major units, an upper hemipelagic sequence $177 \mathrm{~m}$ thick (Upper Miocene to Quaternary) and a lower carbonate ooze sequence $\sim 200 \mathrm{~m}$ thick (Middle-Lower Miocene). The hemipelagic sediments are characterized by higher $\mathrm{U}$ concentrations due to

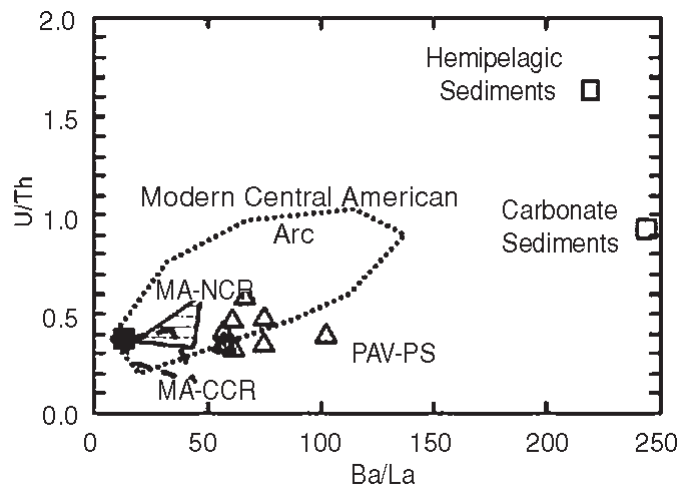

Fig. 7: Ba/La vs. U/Th. The slab component that interacted with the mantle to generate the primitive arc volcaniclasts (PAV) lacked the U-rich sediments that influenced the slab component of the modern arc (area encircled by dotted line). MORB composition represented by filled square.

higher contents of organic matter (Patino et al., 2000). Thus, ratios of $U$ to other trace elements can be used as indicators of the contribution from hemipelagic sediments. Plank et al. (2002) interpreted the lower U/Th ratios of early-middle Miocene lavas from Nicaragua as indicators that the hemipelagic sediments did not contribute to the magma generation process of those magmas. The modern and primitive lavas from Costa Rica have similar U/Th ratios implying less input from the hemipelagic sediments. In modern lavas, the low U/Th ratio is caused by the underplating or scrapping of hemipelagic sediments. In primitive lavas, the low ratios are likely a consequence of the absence of organic-rich hemipelagic sediments. We argue against underplating for the low $\mathrm{U}$ ratios in the primitive arc lavas because the high $\mathrm{Ba} / \mathrm{La}$ ratios for these samples imply a large slab fluid component. In the modern arc the large slab component is associated with steeper angles of subduction which will not favor underplating of subducting sediments.

Outcrops of volcanic material related to a Late Mesozoic arc system have been documented in Nicaragua and Panama (Weyl, 1980; Lissinna et al., 2002). However, in Costa Rica only volcaniclasts represent this time period. Detailed geologic mapping and chemical analyses of volcanic material of the earliest arc (volcani- 
clasts and outcrops) are needed to discern the geographic distribution of the volcanic centers and the source for the volcaniclasts.

\section{REFERENCES}

ABRATIS, M. \& WORNER, G., 2000: Ridge collision, slab-window formation, and the flux of Pacific asthenosphere into the Caribbean real. - Geology, 29(2): $127-130$

BALLANCE, P.F., 1991: Gravity flows and rock recycling on the Tonga landward trench slope: relation to trenchslope tectonic processes. - J. Geol. 99: 817-827.

BAUMGARTNER, P.O., MORA, C.R., BUTTERLIN, J., SIGAL, J., GLACON, G., AZEMA, J. \& BOURGOIS, J., 1984: Sedimentación y paleogeografía del Cretácico y Cenozoico del litoral pacífico de Costa Rica. - Rev. Geol. Amér. Central, 1: 57-136.

BOURGOIS, J., AZEMA, J., BAUMGARTNER, P.O., TOURNON, J., DESMET, A. \& AUBOUIN, J., 1984: The geologic history of the Caribbean-Cocos plate boundary with special reference to the Nicoya Ophiolite Complex and D.S.D.P. results (Legs 67 and 84 off Guatemala): a synthesis. Tectonophysics, 108: 1-32.

CALVO, C. \& BOLZ, A., 1994: Der älteste kalkalkaline Inselbogen-Vulkanismus in Costa Rica: Marine Pyroklastika der Formation Loma Chumico (Alb bis Campan). - Profil, 7: 235-264.

CARR, M.J., FEIGENSON, M.D. \& BENNETT E.A., 1990: Incompatible element and isotopic evidence for tectonic control of source mixing and melt extraction along the Central American arc. - Contrib. Mineral. Petrol. 105: 369-380.

CAS, R.A.F. \& WRIGHT, J.V., 1987: Volcanic Successions. Modern and Ancient. - 528 pags. Ed. Chapman and Hall, London.

CRISS, J.W., 1980: Fundamental parameters calculations on a laboratory microcomputer. - Advances in X-ray Analysis, 23: 93-97.

FEIGENSON, M.D. \& CARR, M.J., 1993: The source of Central American lavas: inferences from geochemical inverse modeling. - Contrib. Mineral. Petrol. 113: 226-235.

FEIGENSON, M.D., CARR, M.J., PATINO, L.C.,
MAHARAJ, S. \& JULIANO, S., 1996: Isotopic identification of distinct mantle domains beneath Central America. - [abstract] GSA Annual Meeting, Denver, 28(7): 380.

FISHER, R.V. \& SCHMINCKE, H.-U., 1984: Pyroclastic rocks. - 472 pags. Springer, Berlin.

HATHWAY, B. \& KELLY, S.P., 2000: Sedimentary record of explosive silicic volcanism in a Cretaceous deepmarine conglomerate succession, northern Antarctic Peninsula. - Sedimentol. 47(2): 451-470.

HAUFF, F., HOERNLE, K., VAN DEN BOGAARD, P., ALVARADO, G. \& GARBE-SCHÖNBERG, D., 2000: Age and geochemistry of basaltic complexes in western Costa Rica: Contributions to the geotectonic evolution of Central America. - Geochem. Geophys. Geosyst., 1, Paper number 1999GC000020 [10,051 words, 8 figures, 7 tables], May 30, 2000.

HERRSTROM, E.A., REAGAN, M.K. \& MORRIS, J.D., 1995: Variations in lava composition associated with flow of asthenosphere beneath southern Central America. - Geology, 23: 617-620.

HEY, R., 1977: Tectonic evolution of the Cocos-Nazca spreading center. - Geol. Soc. Amer. Bull. 88(10): 14041420 .

HILL, I.G., WORDEN, R.H. \& MEIGHAN, I.G., 2000: Yttrium: The immobility-mobility transition during basaltic weathering. - Geology, 28(10): 923-926.

HOERNLE, K., VAN DEN BOGAARD, P., WORNER, R., LISSINNA, B., HAUFF, F., ALVARADO, G.E., GARBE-SCHÖNBERG, D., 2002: Missing history (16-71) Ma of the Galapagos hotspot: implications for the tectonic and biological evolution of the Americas. - Geology, 30(9): 795-798.

KUIJPERS, E.P., 1979: La geología del Complejo Ofiolítico de Nicoya, Costa Rica. - Inf. Sem. Inst. Geogr. Nac. 25: $15-75$.

LEW, L.R., 1983: The geology of the Osa peninsula, Costa Rica: observations and speculations about the evolution of part of the outer arc of the southern Central America orogen. - 128 pags. Pennsylvania State Univ. [Thesis Master].

LISSINNA, B., HOERNLE, K. \& VAN DEN BOGAARD, P., 2002: Northern migration of arc volcanism in western Panama: evidence for subduction erosion? - [abstract] AGU Fall Meeting, San Francisco, EOS 
Trans. 83(47):V11A-1368.

LYNTWYN, J., RUTHERFORD, E., BURKE, K. \& XIA, C., 2001: The geochemistry of volcanic, plutonic and turbiditic rocks from Sumba, Indonesia. - J. Asian Earth Sci. 19(4): 481-500.

MAURY, R.C., DEFANT, M.J., BELLON, H., DE BOER, J.Z., STEWART, R.H. \& COTTON, J., 1995: Early Tertiary arc volcanics from eastern Panama. In: MANN, P. (ed): Geologic and tectonic development of the Caribbean Plate Boundary in Southern Central America. - Geol. Soc. Amer. Spec. Paper, 295: 29-34.

MESCHEDE, M., FRISCH, W. \& SICK, M., 1988: Interpretación geodinámica de los complejos ofiolíticos de Costa Rica. - Rev. Geol. Amér. Central, 8: $1-17$.

MOREY, G.B. \& SETTERHOLM, D.R., 1997: Rare Earth Elements in weathering profiles and sediments of Minnesota: implications for provenance studies. - J. Sedimentary Res. 67(1): 105-115.

PARKER, A., 1970: An index of weathering for silicate rocks. - Geol. Mag. 107: 501-504.

PATINO, L.C., CARR, M.J. \& FEIGENSON, M.D., 2000: Regional and local variations in Central American lavas controlled by variations in sediment input. Contrib. Mineral. Petrol. 138: 265-283.

PINDELL, J.L. \& BARRETT, S.F., 1990: Geologic evolution of the Caribbean region: A plate tectonic perspective. - In: DENGO, G. \& CASE J.E. (eds.): The geology of North America, The Caribbean region H: 405-432.

PLANK, T., BALZER, V. \& CARR, M.J., 2002: Nicaraguan volcanoes record paleoceanographic changes accompanying closure of the Panama gateway. - Geology, 30(12): 1087-1090.

SCHOTT, R.C. \& JOHNSON, C.M., 1998: Sedimentary record of the Late Cretaceous thrusting and collapse of the Salina-Mojave magmatic arc. - Geology, 26(4): 327-330.

SUN, S. \& MCDONOUGH, W.F., 1989: Chemical and isotopic systematics of oceanic basalts: implications for mantle composition and processes. In: SAUNDERS, A.D. \& NORRY, M.J. (eds.): Magmatism in the ocean basins. - Geol. Soc. Amer. Spec. Public. 42: 313-345.

TOURNON, J., 1984: Magmatismes du Mesozoic à l'actuel en Amérique Central: L' example de Costa Rica, des ophiolites aux andesites. - 335 pags. Memoires Sciences Terre, Univ. Pierre et Marie Curie [Thesis Ph.D.].

WEYL, R., 1980: Geology of Central America. - 371 págs. Gebrüder Borntraeger, Berlin.

WOODHEAD, J.D., EGGINS, S.M. \& JOHNSON, R.W., 1998: Magma genesis in the New Britain island arc: further insights into the melting and mass transfer processes. - J. Petrol. 39(9): 1641-1668. 